\title{
Biodegradable polymer composites based on polylactide used in selected 3D technologies (Rapid communication)
}

\author{
Katarzyna Bulanda ${ }^{1), *)}$, Mariusz Oleksy'), Rafał Oliwa1), Grzegorz Budzik ${ }^{2)}$, Małgorzata Gontarz ${ }^{2)}$ \\ DOI: dx.doi.org/10.14314/polimery.2020.7.8
}

\begin{abstract}
As part of the work, new polymer materials were used in 3D printing, which can be used in three technologies depending on the apparatus used: Fused Filament Fabrication (FFF), Melted and Extruded Manufacturing (MEM), Melt Extrusion Polymers (MEP). As part of the work, the properties of obtained polymer composites were examined. Polylactide (PLA) was used as the matrix, and powdered natural ground fillers were used as fillers: bamboo dust (PB), cork dust (PK) and wood dust (PD). In the first part of the work, filaments were received from the tested composites using the filament preparation line made by METACHEM in Torun for use in 3D printers. Samples for mechanical tests were obtained from the filaments thus received by means of an MEP printer and after granulation by injection molding. In the next part of the work, rheological, mechanical and structural properties of obtained composites were examined. It was found that the addition of natural fillers increased the fluidity of the obtained polymeric materials in the case of composite with addition of PK even by $48.73 \%$ compared to unfilled PLA. It was also observed that the composites obtained had lower Charpy impact strength, Rockwell hardness and tensile strength. Observation of the microstructure of the composites using SEM confirmed the even distribution of natural fillers in the polymer matrix, which proves well-chosen parameters of their homogenization in the polymer matrix.
\end{abstract}

Keywords: 3D printing, MEP, FFF, MEM, polymer composites, natural fillers, processing of polymer materials.

\section{Biodegradowalne kompozyty polimerowe na osnowie polilaktydu stosowane w wybranych technologiach 3D}

Streszczenie: Otrzymano nowe materiały polimerowe do zastosowań w druku 3D, które można wyko-
rzystywać, zależnie od stosowanego aparatu, w trzech technologiach: Fused Filament Fabrication (FFF),
Melted and Extruded Manufacturing (MEM), Melt Extrusion Polymers (MEP). Zbadano właściwości wy-
tworzonych kompozytów polimerowych. Jako osnowę zastosowano polilaktyd (PLA), a w charakterze
napełniaczy użyto sproszkowanych w postaci pyłu naturalnych cząstek: bambusa (PB), korka (PK) oraz
drzewnych (PD). Z badanych kompozytów otrzymano filamenty z wykorzystaniem zaprojektowanej
i wykonanej przez METACHEM w Toruniu linii do wytwarzania filamentu stosowanego w drukar-
kach 3D. Z tak uzyskanych filamentów wykonano próbki do badań mechanicznych za pomocą dru-
karki MEP oraz, po zgranulowaniu, metodą wtryskiwania do formy. Zbadano właściwości reologicz-
ne, mechaniczne oraz strukturalne otrzymanych kompozytów. Stwierdzono, że dodatek naturalnych
napełniaczy spowodował zwiększenie płynności materiałów polimerowych, w wypadku kompozytu
z dodatkiem PK nawet o 48.73\% w stosunku do płynności nienapełnionego PLA. Stwierdzono, że otrzy-
mane kompozyty wykazywały mniejsze: udarność według Charpy'ego, twardość według Rockwella
oraz wytrzymałość przy rozciaganiu. Obserwację mikrostruktury badanych kompozytów za pomoca
SEM potwierdziły równomierny rozkład cząstek naturalnych napełniaczy w osnowie polimerowej, co
świadczy o dobrze dobranych parametrach procesu ich homogenizacji. Słowa kluczowe: druk 3D, MEP, FFF, MEM, kompozyty polimerowe, napełniacze naturalne, przetwórstwo tworzyw polimerowych.

\footnotetext{
1) Rzeszow University of Technology, Department of Polymer Composites, al. Powstańców Warszawy 6, 35-959 Rzeszów, Poland.

2) Rzeszow University of Technology, Department of Mechanical Engineering, al. Powstańców Warszawy 8, 35-959 Rzeszów,

Poland.

*) Author for correspondence: k.bulanda@prz.edu.pl
} 
FFF/MEM/MEP technologies are one of the oldest rapid prototyping techniques. FFF/MEM/MEP consists in applying polymer material heated to the melting temperature, which is placed layered on the machine's working table or on previously stamped layers of the printed element using a nozzle. Individual process parameters, i.e. angle and density of the filling, layer height, extruder speed, extrusion temperature and working table temperature are selected each time depending on the filament used. Currently, items manufactured using FFF, MEM or MEP methods are primarily used in education and assembly of prototypes, but also in various applications, for example medical or electrical [1-3]. In order to obtain the desired properties of printed elements, a suitable material is selected, a thermoplastic polymer such as PLA (polylactide), ABS (acrylonitrile-butadiene-styrene), PA (polyamide), PEI (polyetherimide), PET/G (polyethylene terephthalate/glycol) and PEEK (polyether ether ketone). Of these polymers, polylactide has gained a lot of interest in biopolymer research because of its biodegradability and biocompatibility. Depending on the desired properties, PLA is modified in a wide range by the introduction of various additives (e.g. fillers) [4, 5].

Additives modifying the properties of polymer materials have been known for many years. At the beginning they were introduced to reduce the price of the product, change the density of the composite or improve selected properties. Recently, natural fillers have aroused great interest due to many desirable features (biodegradability, low density), moreover they are renewable and cheaper than synthetic or inorganic counterparts. The use of biodegradable materials contributes to environmental protection, which is very important due to current problems with the disposal of products after use. That is why so many scientists are investigating the possibility of using natural additives for polymer materials, such as flax, cellulose, bamboo, wood, silk and wood flour [6].

Recently, there have been many articles about PLAbased composites. The latest example is the work [8] by

a)

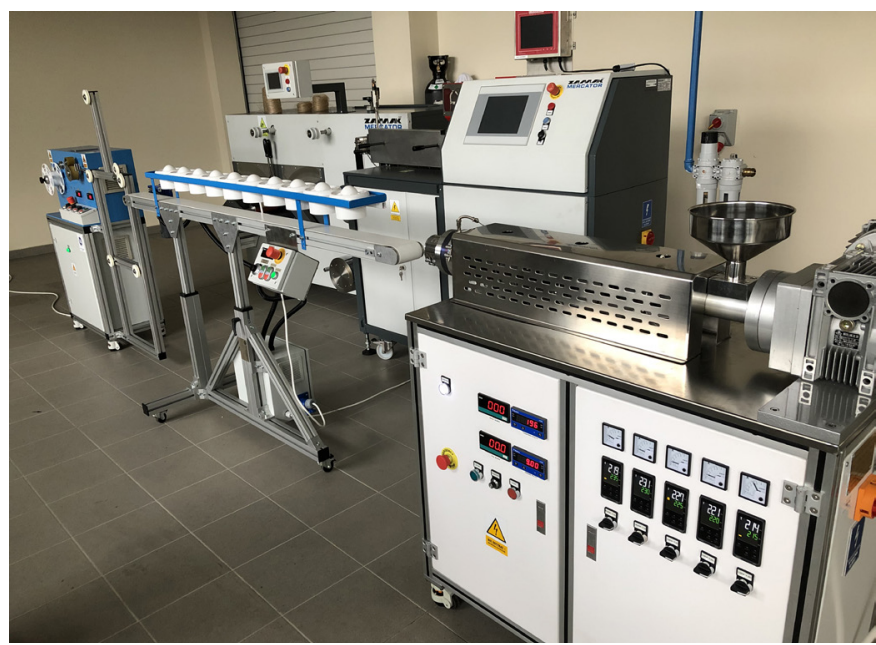

the authors of Zaaba N.F. and Ismail H., in which researchers studied the effect of 10, 20, 30 and $40 \mathrm{wt} \%$ filler content - peanut shell powder - on the selected properties of a composite consisting of polylactide (80 wt \%) and corn starch $(20 \mathrm{wt} \%)$. The obtained results allowed to state that with increasing filler content in the biocomposite, tensile strength and modulus of elasticity increase. Unfortunately, a reduction in the elongation at break parameter was also observed. The best test results were obtained for a composite with $30 \mathrm{wt} \%$ addition of peanut shell powder, also scanning electron microscopy confirmed the improvement of interfacial adhesion at the indicated filling level. Another interesting combination was proposed by Hamdan M.H.M. and others in their work [9], where the authors used rice husk as an addition to the PLA polymer matrix, which is obtained as a by-product of the rice milling process. Scientists have determined the effect of filler content on the composite's mechanical properties such as stretching, bending and impact strength. The addition of a filler caused a decrease in the material's mechanical properties, especially tensile and flexural strength.

This article is devoted to such research on obtaining biodegradable polymeric material.

The aim of the study was determine the mechanical and structural properties of the obtained polymer composites based on PLA matrix.

\section{EXPERIMENTAL PART}

\section{Materials}

The work uses a polymer in the form of a ColorFabb filament, which after granulation was used for subsequent stages of research. The polymer matrix was filled by adding natural powdered fillers: bamboo dust (PB; size $2.0-4.5 \mathrm{~mm}$, density $950 \mathrm{~kg} / \mathrm{m}^{3}$ ), cork dust (PK; size $0.2-0.5 \mathrm{~mm}$, density $55-65 \mathrm{~kg} / \mathrm{m}^{3}$ ) and wood dust (PD; size $2-5.5 \mathrm{~mm}$, density $1400-1500 \mathrm{~kg} / \mathrm{m}^{3}$ ), the additions were also obtained from ColorFabb.

b)

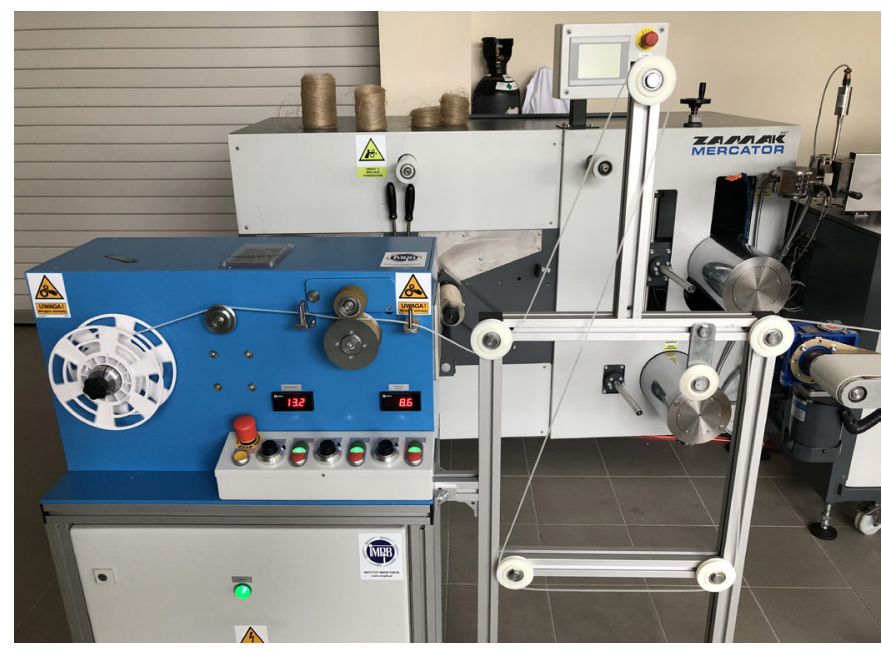

Fig. 1. Designed as part of the work, an original filament production line 
T a b l e 1. Parameters of the injection molding process-obtaining paddles

\begin{tabular}{|c|c|c|c|c|}
\hline \multirow{2}{*}{ Parameter } & \multicolumn{4}{|c|}{ Filament } \\
\hline & PLA & PLA + PD & $\mathrm{PLA}+\mathrm{PB}$ & $\mathrm{PLA}+\mathrm{PK}$ \\
\hline Mold temperature, ${ }^{\circ} \mathrm{C}$ & 50 & 40 & 50 & 50 \\
\hline Injection temperature, ${ }^{\circ} \mathrm{C}$ & 210 & 200 & 210 & 230 \\
\hline Injection pressure, $\mathrm{MPa}$ & 90 & 700 & 750 & 900 \\
\hline Post pressure, $\mathrm{MPa}$ & 85 & 650 & 700 & 850 \\
\hline Plasticizing time, s & 140 & 80 & 120 & 90 \\
\hline Injection time, s & 5 & 5 & 5 & 5 \\
\hline
\end{tabular}

$\mathrm{T}$ a b l e 2. Parameters of the injection molding process - obtaining bars

\begin{tabular}{l|c|c|c}
\hline \multirow{2}{*}{ Parameter } & \multicolumn{2}{c}{ Filament } \\
\cline { 2 - 4 } & PLA & PLA + PD & PLA + PB \\
\hline Mold temperature, ${ }^{\circ} \mathrm{C}$ & 60 & 60 & 60 \\
Injection temperature, ${ }^{\circ} \mathrm{C}$ & 220 & 220 & 220 \\
Injection pressure, $\mathrm{MPa}$ & 90 & 850 & 850 \\
Post pressure, MPa & 85 & 800 & 800 \\
Plasticizing time, s & 120 & 80 & 800 \\
Injection time, s & 5 & 5 & 50 \\
\hline
\end{tabular}

\section{Preparation of the composites}

Prior to introduction into the polymer matrix, the additives were dried at $60^{\circ} \mathrm{C}$ for $24 \mathrm{~h}$, pulverized in powder form with a planetary ball mill and then sieved through a $0.06 \mathrm{~mm}$ sieve [10]. The composites needed for the determinations were received after mixing together the respective amounts of the individual components: $69 \mathrm{wt} \%$ PLA, 30 wt \% filler, 1 wt \% compatibilizer (Fusabond E226 from DuPont). Homogenization of the components of the composition was carried out using a Cooperion twin screw extruder with the following parameters: 400 screw rotation/min, extrusion efficiency of $4 \mathrm{~kg} / \mathrm{h}$ and in the temperature range from 180 to $210^{\circ} \mathrm{C}$. Then, from the composites thus obtained, filaments with a diameter of $2.85 \pm 0.05 \mathrm{~mm}$ were used for printing in MEP technology on a proprietary filament preparation line specially designed and obtained by METACHEM in Torun (Fig. 1) in the extrusion temperature range of $180^{\circ} \mathrm{C}$ up to $230^{\circ} \mathrm{C}$.

Full specification of received filaments: diameter $2.85 \mathrm{~mm}$; tolerance \pm 0.05 ; roundness $\geq 95$; application temperature is in the range: for PLA $180-210^{\circ} \mathrm{C}$, PLA + PD $195-220^{\circ} \mathrm{C}$, $\mathrm{PLA}+\mathrm{PB} 190-210^{\circ} \mathrm{C}, \mathrm{PLA}+\mathrm{PK} 210-230^{\circ} \mathrm{C}$. The temperature range for each of the composites was selected based on literature data of similar materials [11, 12], which in the course of the research proved to be accurate also for the obtained materials.

Samples for mechanical tests were received from the filaments obtained in this way using an MEP printer and after granulating by injection molding using Haake MiniJet II mini injection molding machine. The parameters of the injection process are summarized in Table 1 and Table 2.
For comparison, fittings were obtained for testing with the Ultimaker 3 Extended printer with the following printing parameters: rectilinear type of filing; $45^{\circ}$ filling angle; $100 \%$ filling density; $9.2 \mathrm{~mm}$ layer height; $70 \mathrm{~mm} / \mathrm{s}$ extruder speed; $210^{\circ} \mathrm{C}$ extrusion temperature; $60^{\circ} \mathrm{C}$ working platform temperature and $45 \mathrm{~min}$ process duration.

\section{Methods of testing}

As part of the work, a number of determinations were carried out, which allowed to determine the properties of the polymer materials obtained:

- MFR, melt mass flow index was determined using a DYNISCO 4781 Plastometer. Samples of approximately $4 \mathrm{~g}$ were filled into a suitably heated apparatus, preload applied for $240 \mathrm{~s}$, after that time the load was changed to proper $-2.16 \mathrm{~kg}$ and measurement began. The sample extruded from the nozzle was cut every 10 seconds and then weighed. Three measurements were made for each of the series.

- Rockwell hardness was carried out using a hardness tester, Zwick/Roell, at ambient temperature. The sample was placed in the apparatus, the specific load (load at which the indenter will sink to a thickness of $0.15-0.35 \mathrm{~mm}$ ) was applied and the measurement began for 30 seconds. Ten determinations were carried out for each of the series.

- Charpy impact strength was determined using PSW GEHARD ZORN impact hammer with a strength of $1 \mathrm{~J}$. The test specimens were placed horizontally on the machine's supports in such a way that the hammer hits the center of the fitting edge. Five measurements were 
taken for each series, and the result was displayed on the camera monitor.

- The determination of strength properties during the static tensile test was performed on an INSTRON 5967 testing machine at ambient temperature. Appropriate process parameters (stretching rate, sample dimensions) were set, then the fittings were placed in machine holders. The progress of the process was observed on a computer, the measurement continues until the assumed value, e.g. stress, deformation or until the fitting breaks. The results were recorded in the form of chats and tables.

- Hitachi SEM TM3000 scanning electron microscope was used to observe the microstructure of the materials produced. Before observation, polymer and composite samples were sprayed with a palladium gold layer. Observations were made using a $5 \mathrm{keV}$ voltage.

\section{RESULTS AND DISCUSSION}

In order to determine the effect of the type of filler in the composite on the functional properties of the obtained polymeric materials, rheological, mechanical and structural tests were performed.

\section{Mechanical and rheological properties}

The results of the tests of the melt mass flow index, hardness, impact strength and strength at static tensile are summarized in the Table 3.

The melt mass flow index (MFR) specified allowed to determine the effect of fillers used on the fluidity of the polymer materials obtained. The results of these studies are summarized in Table 3 on the basis of which it can be concluded that the introduced natural fillers increase the fluidity of the composition. $M F R=13.10 \mathrm{~g} / 10 \mathrm{~min}$ was obtained for unfilled PLA. However, the addition of the fillers used increased the $M F R$, in the case of the PLA + PK composition even to about 25.55 g/10 min (composite with the addition of PK has the highest volume of filler because PK is the lightest among the added ingredients). It can be assumed that despite drying, water is still present in the natural fillers used, because the fluidity of the materials is improved. Despite drying, bound water still remains in the filler crystal lattice, which can plasticize PLA, because the polymer is sensitive to moisture $[13,14]$. Such an effect will allow easy molding of elements in injection technology, and the resulting products will also be environmentally friendly.

Based on the received results of the Rockwell hardness determination, it was found that the samples containing selected fillers have a lower hardness compared to the unfilled material. It can be concluded that the processes of processing natural fillers, which include milling, high shear homogenization, crushing and purification of the raw material, cause damage to the crystalline phase of the additive, which negatively affects the mechanical properties [11]. We observe that the best test results were obtained for unfilled PLA, and the determined hardness depends on the technique of received test samples. As could be expected, much better results were obtained for fittings received in the injection process (Table 3). In addition, also samples obtained from composites in the

$\mathrm{T}$ a $\mathrm{b} 1 \mathrm{e}$ 3. Summary of the results of research on rheological and mechanical properties of composites

\begin{tabular}{|c|c|c|c|c|}
\hline \multirow{2}{*}{ Parameter } & \multicolumn{4}{|c|}{ Filament } \\
\hline & PLA & PLA + PD & $P L A+P B$ & PLA + PK \\
\hline$M F R, \mathrm{~g} / 10 \mathrm{~min}$ & $\begin{array}{c}13.10 \pm 0.2 \\
{\left[200^{\circ} \mathrm{C} ; 2.16 \mathrm{~kg}\right]}\end{array}$ & $\begin{array}{c}19.17 \pm 0.5 \\
{\left[200^{\circ} \mathrm{C} ; 2.16 \mathrm{~kg}\right]}\end{array}$ & $\begin{array}{c}19.23 \pm 0.9 \\
{\left[190^{\circ} \mathrm{C} ; 2.16 \mathrm{~kg}\right]}\end{array}$ & $\begin{array}{c}25.55 \pm 1.3 \\
{\left[210^{\circ} \mathrm{C} ; 2.16 \mathrm{~kg}\right]}\end{array}$ \\
\hline \multicolumn{5}{|c|}{ Test samples obtained by means of 3D printing } \\
\hline Hardness, $\mathrm{N} / \mathrm{mm}^{2}$ & $91.30 \pm 14.3$ & $39.47 \pm 4.9$ & $37.70 \pm 3.8$ & $58.47 \pm 2.4$ \\
\hline Impact strength, $\mathrm{kJ} / \mathrm{m}^{2}$ & $23.37 \pm 13.1$ & $15.92 \pm 1.7$ & $14.29 \pm 8.0$ & $10.32 \pm 0.8$ \\
\hline Young's modulus, $\mathrm{MPa}$ & $2231.12 \pm 31.6$ & $760.81 \pm 44.3$ & $1846.49 \pm 42.6$ & $1681.63 \pm 28.1$ \\
\hline Strain at break, \% & $4.57 \pm 0.6$ & $5.94 \pm 2.1$ & $10.10 \pm 7.8$ & $3.28 \pm 1.3$ \\
\hline Stress at break, MPa & $53.42 \pm 2.6$ & $26.14 \pm 2.2$ & $26.15 \pm 3.8$ & $34.4 \pm 3.4$ \\
\hline \multicolumn{5}{|c|}{ Test samples obtained using injection technology } \\
\hline Hardness, $\mathrm{N} / \mathrm{mm}^{2}$ & $147.78 \pm 16.2$ & $127.35 \pm 7.4$ & $129.57 \pm 10.4$ & $93.63 \pm 10.6$ \\
\hline Change of the hardness, $\%$ & -38 & -69 & -71 & -38 \\
\hline Impact strength, $\mathrm{kJ} / \mathrm{m}^{2}$ & $34.36 \pm 11.0$ & $32.02 \pm 8.1$ & $26.14 \pm 4.9$ & $19.19 \pm 3.4$ \\
\hline Change of the impact strenght, $\%$ & -32 & -50 & -45 & -46 \\
\hline Young's modulus, $\mathrm{MPa}$ & $2503.81 \pm 67.8$ & $2656.04 \pm 33.2$ & $2644.06 \pm 105.6$ & $1900.33 \pm 62.2$ \\
\hline Change of the Young's modulus, \% & -11 & -71 & -30 & -12 \\
\hline Strain at break, \% & $6.55 \pm 2.2$ & $3.69 \pm 0.5$ & $5.35 \pm 1.3$ & $8.11 \pm 1.8$ \\
\hline Change of the strain at break, $\%$ & -30 & +61 & +89 & -60 \\
\hline Stress at break, $\mathrm{MPa}$ & $54.71 \pm 4.1$ & $41.07 \pm 3.1$ & $36.31 \pm 2.1$ & $35.09 \pm 1.8$ \\
\hline Change of the stress at break, $\%$ & -2 & -36 & -28 & -2 \\
\hline
\end{tabular}


injection process are characterized by higher hardness compared to samples made using 3D printing. This is probably due to the greater uniformity of the samples [3].

Analyzing the received results of the impact strength of the tested polymer materials, it was found that the parts obtained by injection molding were also characterized by better test results compared to the parts obtained by MEP technology. The worst test results were received for the PLA + PK composite regardless of how the samples were obtained $\left(19.19 \mathrm{~kJ} / \mathrm{m}^{2}\right.$ by injection molding, $10.32 \mathrm{~kJ} / \mathrm{m}^{2}$ by MEP technology).

Analyzing the results of strength tests at static tensile composites combined in Table 3, it was also found that samples made by injection molding had higher values of Young's modulus and breaking stress compared to samples made in MEP technology. The lowest values of the elasticity modulus were observed for the PK filled composite moldings obtained by 3D printing (Table 3). The best results were obtained for composite moldings containing PD and PB obtained in the injection technology (PLA + PD 2656.04 MPa and PLA + PB 2644.06 MPa, respectively). Based on the deformation results at break, it was found that better composites obtained in 3D printing technology compared to molded parts obtained by injection molding were received for composites filled with PD and PB (Table 3).

\section{Morphological analyses}

The morphology of brittle fractures of the tested composited was observed using SEM and the results of these observations are shown in Fig. 2.

Analyzing the results of the SEM study of the obtained composites shown in Fig. 2, an even distribution of the fillers used in the polymer matrix was observed. Aggregates and agglomerates of introduced additives were not observed, which may indicate well-

chosen homogenization conditions [8]. It was observed in the case of PLA composite with the addition of PB (Fig. 2a) and PD (Fig. 2c) that the fillers used have the form rods with length in the range of 20-200 $\mu \mathrm{m}$ and diameter in the range $20-40 \mu \mathrm{m}$. However, in the case of PLA + PK (Fig. 2b), we observe a spherical filler in size 20-60 $\mu \mathrm{m}$. It can be seen that the selected additives are well embedded in the matrix and the filler surface is wetted by the polymer, this indicates good interaction and adhesion between the filler and the matrix [8]. The resulting composites show good adhesion to the polymer, which could have been caused by the addition of a coupling agent [11] (1 wt \% compatibilizer - Fusabond E226).

\section{CONCLUSIONS}

The proprietary line for obtaining composites based on polymer materials in the form of filament has been developed, which allows to increase the range of polymer materials used in FFF/MEM/MEP technologies.
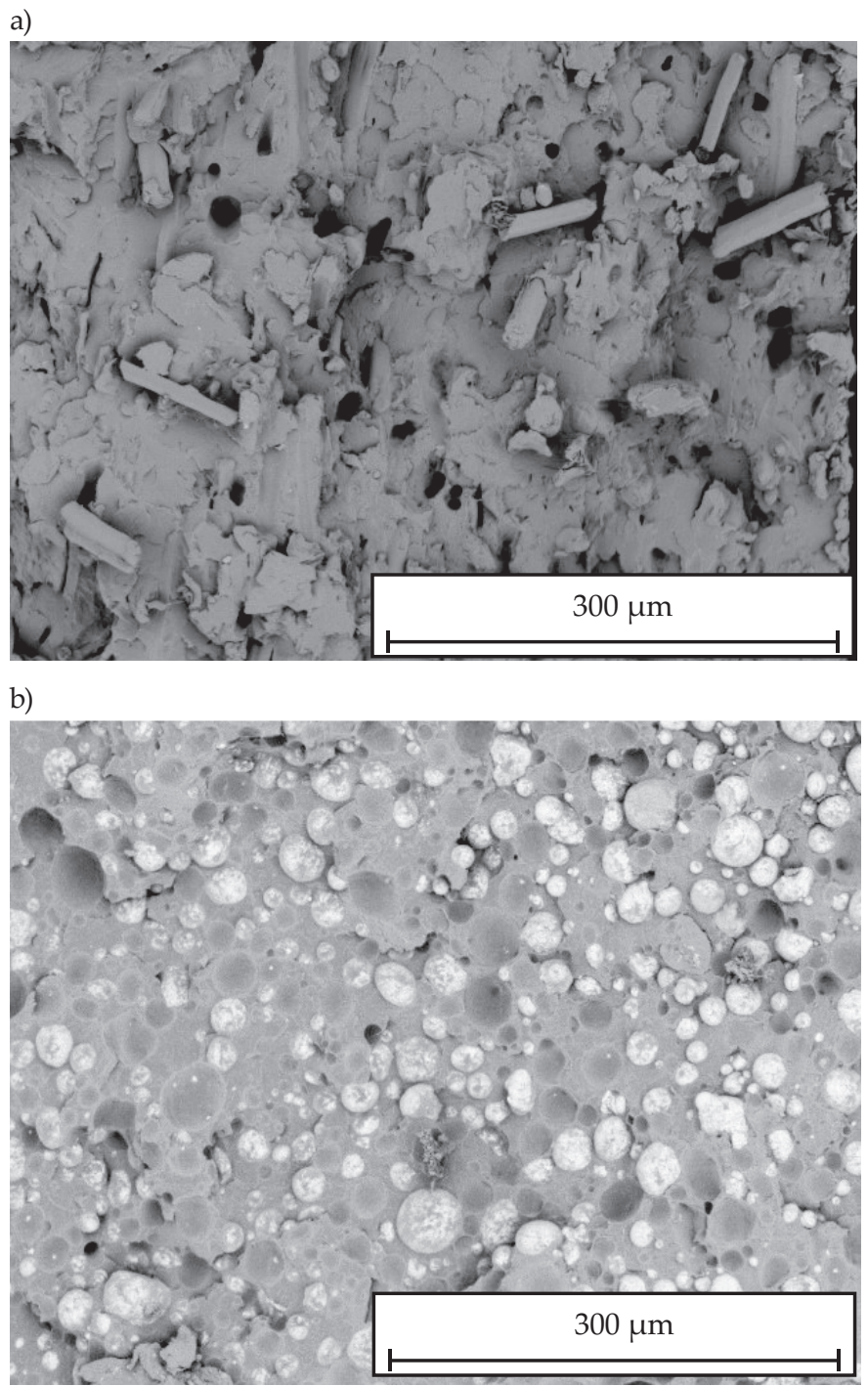

c)

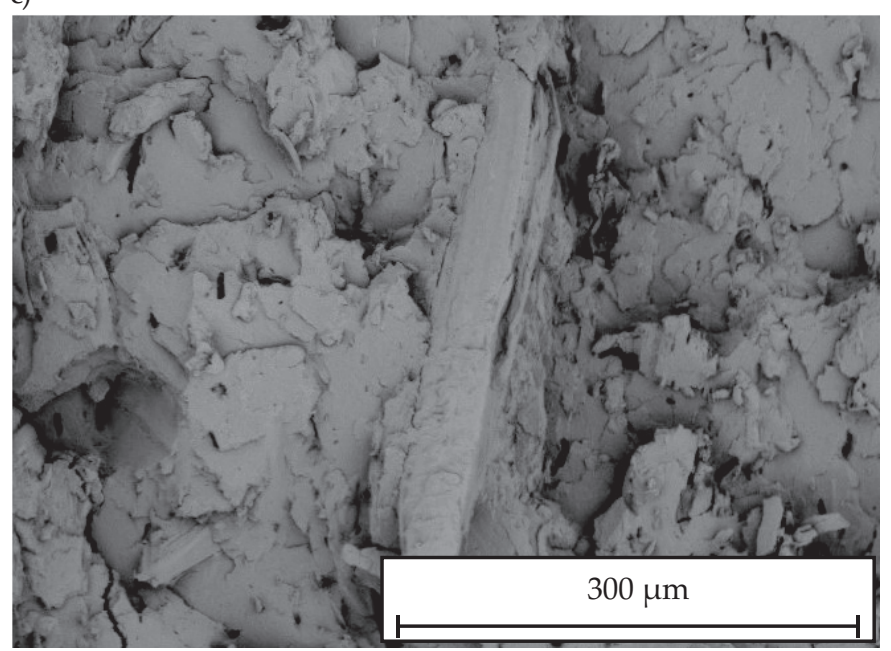

Fig. 2. SEM test results for the composition: a) $P L A+P B, b) P L A$ + PK, c) PLA + PD

- Samples obtained by injection molding had significantly better mechanical and functional properties in comparison to samples obtained using an MEP printer.

- The addition of the natural filler introduced to the polymer matrix has improved the fluidity of the mate- 
rial $(M F R)$, and the material with the highest fluidity is the PK reinforced composite $(M F R=25.55 \mathrm{~g} / 10 \mathrm{~min})$. Unfortunately, a decrease in Charpy impact strength and Rockwell hardness was observed for the resulting composites.

- Samples obtained by injection molding are more rigid - they have a higher Young's modulus. Unfilled PLA was characterized by the greatest stress needed to break the sample, both for molded parts obtained by injection molding and 3D printing (54.71 MPa and 53.42 $\mathrm{MPa}$, respectively).

- Natural fillers are characterized by even distribution of particles in the polymer matrix due to the application of appropriate homogenization and compatibilizer conditions.

\section{REFERENCES}

[1] Buj-Corral I., Dominguez-Fernandez A., DuranLlucia R.: Materials 2019, 12 (23), 3834. https://doi.org/10.3390/ma12233834

[2] Oleksy M., Budzik G., Kozik B. et al.: Polimery 2017, $61,3$. https://doi.org/110.14314/polimery.2017.003

[3] Budzik G., Magniszewski M., Przeszłowski Ł. et al.: Polimery 2018, 63, 830.

https://doi.org/10.14314/polimery.2018.11.13

[4] Liu Z., Lei Q., Xing S.: Journal of Materials Research and Technology 2019, 8 (5), 3741. https://doi.org/10.1016/j.jmrt.2019.06.034

[5] Heidari-Rarani M., Rafiee-Afarani M., Zahedi A.M.: Composites Part B: Engineering 2019, 175, 107147. https://doi.org/10.1016/j.compositesb.2019.107147

[6] Battegazzore D., Noori A., Frache A.: Journal of Composite Materials 2018, 53 (6), 783.

https://doi.org/10.1177\%2F0021998318791316

[7] Salasińska K., Polka M., Gloc M. et al.: Polimery 2016, 61, 255. https://doi.org/10.14314/polimery.2016.255

[8] Zaaba N.F., Ismail H.: AIP Conference Proceedings 2019, 2068, 020073. https://doi.org/10.1063/1.5089372

[9] Hamdan M.H.M., Siregar J.P., Rejab M.R.M. et al:: International Journal of Preision Engineering and Manufacturing-Green Technology 2019, 1 (6), 113. https://doi.org/10.1007/s40684-019-00017-4

[10] Aranda-Garcia F.J., Gonzalez R., Jasso-Gastinel C.F. et al.: International Journal of Polymer Science 2015, 2015, 7 . http://dx.doi.org/10.1155/2015/343294

[11] Mokhena T.C., Sefadi J.S., Sadiku E.R. et al.: Polymers 2018, 10, 1363. http://dx.doi.org/10.3390/polym10121363

[12] Daver F., Lee K.P.M., Brandt M. et al.: Composites Science and Technology 2018, 168, 230. http://dx.doi.org/10.1016/j.compscitech.2018.10.008

[13] Ayrilmis N., Kariz M., Kwon J.H. et al.: The International Journal od Advanced Manufacturing Technology 2019, 102, 5. http://dx.doi.org/10.1007/s00170-019-03299-9

[14] Nowak B., Pająk J.: Archives of Waste Management and Environmental Protection 2010, 12, 2.

Received 2 III 2020. 